\title{
Systematic 1:500 000 mapping in the Peary Land region, North Greenland
}

\author{
Niels Henriksen
}

The second season of a three year systematic field mapping programme in the Peary Land region, north of latitude $81^{\circ} \mathrm{N}$ and east of longitude $40^{\circ} \mathrm{W}$, was carried out from June to August 1979. The aim of the programme is to produce a 1:500 000 map sheet of eastern North Greenland and to investigate the geological framework of the region. As in 1978 the expedition was carried out in cooperation with a surveying group from the Geodetic Institute, Copenhagen, who mainly worked in the region west of Peary Land establishing ground control points for a new topographic map of North Greenland.

The base camp established at the mouth of Jørgen Brønlund Fjord again this year served as the operation centre for two small helicopters and a sтоL aircraft. The expedition numbered 34, comprising 12 geological two-man parties and supporting personnel. The geological parties were divided into several working groups. Two parties worked in the Precambrian platform area between Wandel Dal and Danmark Fjord (fig. 3), four parties in the Lower Palaeozoic platform sequence in southern Peary Land and three parties mapped the mainly Lower Palaeozoic sequence in the fold belt area north of Frederick E. Hyde Fjord. Quaternary geological investigations were carried out by one team and another team sampled for palaeomagnetic investigations. Collection of stream sediments for a geochemical survey was undertaken by all parties, while one team carried out a special sampling programme.

The second year's work expanded and refined the mapping initiated in 1978 in the Proterozoic - Lower Palaeozoic platform area and a series of detailed investigations of certain lithological, palaeontological and stratigraphical aspects of the succession were carried out. In general the mapping in the area between Danmark Fjord and Frederick E. Hyde Fjord is now complete. Mapping in the fold belt area north of Frederick E. Hyde Fjord was initiated in 1979 and the eastern part of the area was covered. A reconnaissance cross section through the western part of Kronprins Christian Land was carried out in preparation for the general mapping of this area. The areas remaining to be mapped in 1980 thus comprise the western half of the fold belt area north of Frederick E. Hyde Fjord and the Kronprins Christian Land area east of Danmark Fjord. More than two thirds of the region has been covered and it is expected that the remaining areas can be covered in 1980 as planned.

The first two years' systematic mapping in the Peary Land region has supplied a large amount of geological information. Preliminary results from the first year's expedition are presented by the individual geologists in a special report ('Report on the 1978 geological expedition to the Peary Land region, North Greenland'. Rapp. Grønlands geol. Unders. no. $88,1979)$. It is intended to prepare a similar report of the results from the 1979 work. The present report is based on an internal GGU report ('Express report, GGU Peary Land $\left.1979^{\prime}\right)$ to which all participating geologists contributed immediately after the end of the field season. 


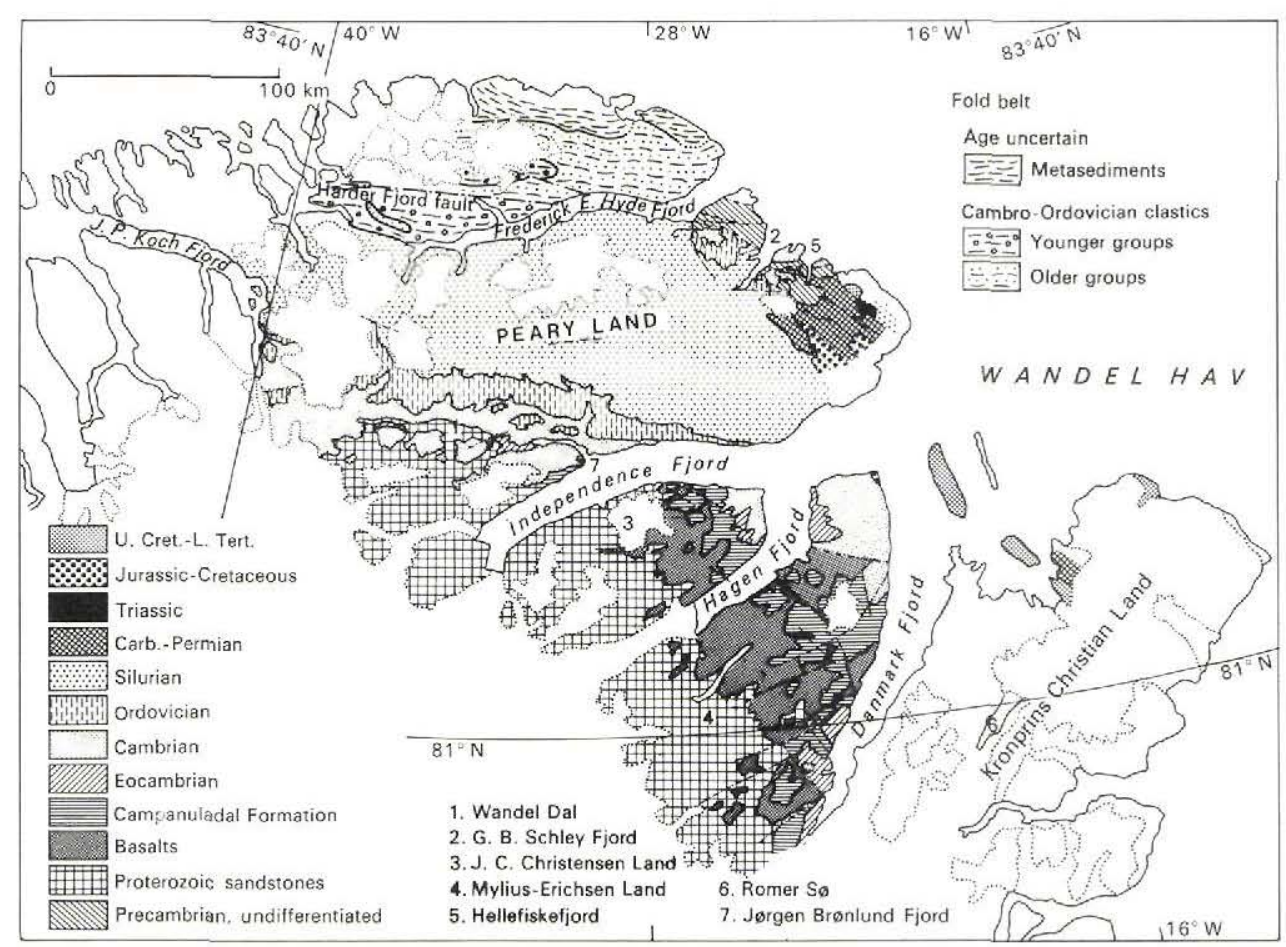

Fig. 3. Geological sketch map of the Peary Land region, eastern North Greenland, showing results of mapping in 1978-1979.

\section{Geological investigations}

The general geology of the mapped area in the Peary Land region was described in the 1978 report. A more than $8000 \mathrm{~m}$ thick succession of flat-lying Proterozoic - Silurian platform sediments outcrops south of the fold belt in the area south of Frederick E. Hyde Fjord. To the north of this fjord occurs an east-west trending fold belt of Lower Palaeozoic age. The rocks in the fold belt comprises a sequence of (?)uppermost Proterozoic to Silurian sediments, mainly deposited on the continental slope to the north of the platform region. Upper Palaeozoic to Lower Tertiary sediments (3000 m thick) forming the Wandel Sea basin outcrop in the eastern part of the Peary Land region.

The oldest part of the platform sequence outcrops mainly south of Independence Fjord. It is a sequence of Proterozoic sandstones about $1700 \mathrm{~m}$ thick which was investigated by $\mathrm{J}$. Collinson and R. E. Bevins of Keele University. Their 1979 work mainly led to a refinement of previous investigations (Collinson, 1979) and to the recognition of equivalents to the Proterozoic sediments in the area around G. B. Schley Fjord in easternmost Peary Land. They also carried out some detailed studies of the overlying part of the Precambrian succession.

The overlying Proterozoic basalt succession (Jepsen \& Kalsbeek, 1979) was investigated by H. Jepsen (GGU) and R. J. Suthren (York Univ.). It covers an area of about $10000 \mathrm{~km}^{2}$ 
in J. C. Christensen Land and Mylius-Erichsen Land and varies in thickness between c. 100 $\mathrm{m}$ and $1350 \mathrm{~m}$. The sequence has been divided into a lower basal unit, a middle aphyric unit and an upper porphyric unit. A number of marker horizons with a large lateral extent can be traced over most of the area and have facilitated the stratigraphical correlation between the individual sections. After the termination of the volcanic activity the area was peneplaned presumably removing the basalts deposited beyond the present exposures. A previous larger extension of the basalt area can be deduced from the existence of ac. $500 \mathrm{~m}$ thick sequence of basalts found in the Hellefiskefjord area in easternmost Peary Land, part of which can be safely correlated with part of the aphyric unit in J. C. Christensen Land.

The lower Palaeozoic sequence in the platform area in southern Peary Land was mainly mapped in 1978 (Peel, 1979; Lane \& Thomas, 1979; Pedersen, 1979) and a series of special investigations were carried out in 1979. J. Ineson (Keele Univ.) studied the sedimentology and stratigraphy of the Cambrian carbonate sequence from J. P. Koch Fjord to Independence Fjord. The work was mainly concentrated on the Lower-Middle Cambrian Brønlund Fjord Group (Peel, 1979), which is dominated by thin-bedded fine-grained carbonates interbanded with breccia sheets. J. Ineson interprets the breccia sheets as carbonate debris flows towards the north and west and tentatively assigns the majority of the Brønlund Fjord Group to a slope environment in this area. The Late Cambrian Tavsens Iskappe Group (Peel, 1979) of thin bedded carbonates and current worked grainstones reflect shallow water conditions with a sequence prograding from south to north. P. Frykman (Copenhagen Univ.) made a special study of the carbonate sedimentology of the lowest member of the Brønlund Fjord Group which represents a transition to the underlying clastic Buen Formation. J. Mabillard (Nottingham Univ.) checked the previous photogeological mapping of south-eastern Peary Land (Pedersen, 1979) and collected samples for micropalaeontological investigations. A full sequence of samples from the Ordovician and Silurian platform sediments in southern Peary Land was collected, in total about 450 samples intended primarily for conodont studies. J. Peel (GGU) together with J. Ineson continued last year's studies on the Upper Cambrian Tavsens Iskappe Group in which seven formations are now recognised.

The Lower Palaeozoic sedimentary development and the boundary relations between the platform succession in the south and the fold belt in the north were studied by J. M. Hurst (GGU) and F. Surlyk (Copenhagen Univ.). They distinguished a 3-4 km thick succession of trough sediments of Cambrian to Silurian age to the south of the prominent E-W trending Harder Fjord fault and were able to correlate these with the metamorphosed clastic sediments north of the fault. Graptolites found in the middle part of the succession south of the Harder Fjord fault suggest a mainly Cambro-Ordovician age for the lower and middle part of this turbiditic succession and a Silurian age for the upper part. Trough sedimentation from at least Lower Cambrian to Upper Silurian time was apparently related to syn-sedimentary E-W trending faults which delimitated the shelf edge to the south.

S. Schack Pedersen (Copenhagen Univ.) mapped the area around the central and inner parts of Frederick E. Hyde Fjord and studied especially the structural transition between the flat lying succession on the platform and the folded strata south of the Harder Fjord fault. In the folded area he distinguished three phases of deformation - resulting in both thrusting and superimposed folding of the Cambrian to Silurian clastic succession.

The eastern part of the fold belt north of the Harder Fjord fault was mapped by J. D. Friderichsen (GGU), A. K. Higgins (GGU) and N. J. Soper (Sheffield Univ.). They divided this region into a southern moderately deformed area in which a lithostratigraphy has been 
established, and a northerly intensely deformed area in which it has only been possible to map lithological units. The previously established tripartite stratigraphy from this area (Dawes \& Soper, 1973) was confirmed and expanded with the discovery of a quartzite unit below the previously known oldest part of the sequence. From bottom to top the succession comprises an unnamed quartzite unit overlain by the Paradisfjeld Group of carbonates and calc-phyllites, followed by the main flysch sequence of the Polkorridoren Group, and a varied suite of flyschoid sediments termed the Sydgletscher Group. The two highest groups can each be divided into five or six units, and fossil evidence from the middle of the Sydgletscher Group indicates a Middle to Upper Ordovician age (J. Hurst \& F. Surlyk, in press). A Cambro-Ordovician age for the main sequence is thus likely, while the youngest unit of the Sydgletscher Group could be Silurian. In the northern intensely deformed area phyllitic, calcareous and quartzitic sediments have been divided into five lithological units. Some of these are equivalent to the flyschoid rocks to the south, but correlation has not been possible.

Three main coaxial east-west trending fold phases are recognized in the fold belt north of the Harder Fjord fault. All three fold phases increase in intensity northwards with development of pervasive cleavage and schistosity, and increasing metamorphic grade.

$\mathrm{N}$. Springer (Copenhagen Univ.) collected samples for radiometric dating mainly from the metamorphic zone of the fold belt. The rocks collected were mainly low grade metasediments of pelitic character but some amphibolite facies assemblages were obtained from the most northerly areas. A suite of samples from the unmetamorphosed Proterozoic sandstone sequence of Independence Fjord was also collected.

John Peel (GGU) made a reconnaissance transverse section through the western part of Kronprins Christian Land between Danmark Fjord and Romer Sø. He was able to recognize a sequence of Lower Palaeozoic rocks comparable to part of the succession described from southern Peary Land. The results obtained form a valuable basis for the 1980 systematic mapping of this region.

N. Abrahamsen (Århus Univ.) and C. Marcussen (Århus Univ.) are undertaking palaeomagnetic investigations on a considerable part of the rock sequence known from the Peary Land region. In 1979 they collected more than 1100 orientated samples mainly representing various parts of the Proterozoic platform sequence and the lowermost Palaeozoic sequence. In addition to this they collected a series of post-glacial unconsolidated lake sediments and also orientated samples from post-glacial marine silt banks near Jørgen Brønlund Fjord. They also measured magnetic susceptibility of many of the exposed rock sequences to provide a framework for interpretation of aeromagnetic data.

The regional geochemical reconnaissance survey initiated in 1978 (Ghisler et al., 1979) was continued with the collection of stream sediments as an integral part of the systematic geological mapping programme. The purpose of this programme is to provide information for an evaluation of the mineral potential and to obtain general geochemical data. A total of about 470 stream sediments were collected representing both sand and silt samples spread through the whole region.

Quaternary geological investigations were carried out by S. Funder (Copenhagen Univ.) and C. Hjort (Lund Univ.) and aimed at establishing a stratigraphical framework which, combined with subsequent aerial photo interpretation, will permit compilation of a Quaternary map on a scale of 1:500 000. Representative localities were visited in coastal areas in the entire region, with particular emphasis on localising and dating the outer limits of the ice 
cover and investigating post-glacial features. From these studies it is concluded that the main Greenland ice sheet formerly extended into at least the south-eastern parts of Peary Land and that the major fjords (Independence Fjord, Hagen Fjord, Danmark Fjord) served as major outlets for the ice sheet. The amount of post-glacial isostatic rebound is indicated by the highest marine deposits, found at altitudes between 40 and $110 \mathrm{~m}$. A significant find of a possible interglacial sequence in south-east Peary Land may contribute to the understanding of the interglacial development in the high arctic region.

\title{
References
}

Collinson, J. D. 1979: The Proterozoic sandstones between Heilprin Land and Mylius-Erichsen Land, eastern North Greenland. Rapp. Grønlands geol. Unders. 88, 5-10.

Dawes, P. R. \& Soper, N. J. 1973: Pre-Quaternary history of North Greenland. In Pitcher, M. G. (edit.). Arctic Geology. Mem. Amer. Ass. Petrol. Geol. 19, 117-134.

Ghisler, M., Henriksen, N., Steenfelt, A. \& Stendal, H. 1979: A regional, reconnaissance, geochemical survey in the Proterozoic-Phanerozoic platform succession of the Peary Land region, North Greenland. Rapp. Grønlands geol. Unders. 88, 85-91.

Hurst, J. M. \& Surlyk, F. in press: Notes on the Lower Palaeozoic clastic sediments of Peary Land, North Greenland. Submitted to Rapp. Grønlands geol. Unders.

Jepsen, H. F. \& Kalsbeek, F. 1979: Igneous rocks in the Proterozoic platform of eastern North Greenland. Rapp. Grønlands geol. Unders. 88, 11-22.

Lane, P. D. \& Thomas, A. T. 1979: Silurian carbonate mounds in Peary Land, North Greenland. Rapp. Grønlands geol. Unders. 88, 51-54.

Pedersen, S. A. Schack 1979: Structural geology of central Peary Land, North Greenland. Rapp. Grønlands geol. Unders. 88, 55-62.

Peel, J. S. 1979: Cambrian - Middle Ordovician stratigraphy of the Adams Gletscher region, southwest Peary Land, North Greenland. Rapp. Grønlands geol. Unders. 88, 29-39.

\section{Early Cambrian microfossils from the Portfjeld Formation, Peary Land, eastern North Greenland}

\author{
John S. Peel
}

The Portfjeld Formation of eastern North Greenland is a dominantly carbonate sequence which, in its type area around Jørgen Brønlund Fjord, Peary Land, lies between the mainly clastic intervals of the Morænesø Formation, below, and the Buen Formation of early Cambrian age, above (Jepsen, 1971). In J. C. Christensen Land and Valdemar Glückstadt Land, to the east and south-east, the formation lies variously on sandstones of the Campanuladal Formation or dolomites of the Fyns Sø Formation (O'Connor, 1979). The age of the Portfjeld Formation has not previously been known with any degree of certainty, although 